\title{
Nonlinear Dose-Dependent Impact of D1 Receptor Activation on Motor Cortex Plasticity in Humans
}

\author{
Shane Fresnoza, Walter Paulus, Michael A. Nitsche, ${ }^{\star}$ and Min-Fang Kuo* \\ Department of Clinical Neurophysiology, Georg-August-University, 37075 Göttingen, Germany
}

\begin{abstract}
The neuromodulator dopamine plays an important role in synaptic plasticity. The effects are determined by receptor subtype specificity, concentration level, and the kind of neuroplasticity induced. D1-like receptors have been proposed to be involved in cognitive processes via their impact on plasticity. Cognitive studies in humans and animals revealed a dosage-dependent effect of D1-like receptor activation on task performance. In humans, D1-like receptor activation re-establishes plasticity under D2 receptor block. However, a dosagedependent effect has not been explored so far. To determine the impact of the amount of D1-like receptor activation on neuroplasticity in humans, we combined sulpiride, a selective D2 receptor antagonist, with the dopamine precursor L-DOPA $(25,100$, and $200 \mathrm{mg})$ or applied placebo medication. The impact on plasticity induced by anodal and cathodal transcranial direct current stimulation (tDCS) was compared with the impact on plasticity induced by excitatory and inhibitory paired associative stimulation (PAS) at the primary motor cortex of healthy humans. Stimulation-generated cortical excitability alterations were monitored by transcranial magnetic stimulation-induced motor-evoked potential amplitudes. D1-like receptor activation produced an inverted U-shaped dose-response curve on plasticity induced by both facilitatory tDCS and PAS. For excitability-diminishing tDCS and PAS, aftereffects were abolished or converted trendwise into facilitation. These data extend findings of dose-dependent inverted U-shaped effects of D1 receptor activation on neuroplasticity of the motor cortex.
\end{abstract}

Key words: dopamine; dopamine receptors; neuroplasticity; paired associative stimulation; transcranial direct current stimulation; transcranial magnetic stimulation

\section{Introduction}

Dopamine improves learning and memory formation in humans and animals (Floresco and Phillips, 2001; Knecht et al., 2004; Flöel et al., 2005). Dopamine's impact on neuroplasticity might help to explain these effects. Dopamine enhances long-term potentiation (LTP) and long-term depression (LTD) in animals, and LTP-/LTD-like plasticity in humans (Otani et al., 1998; Bailey et al., 2000). Moreover, impaired cognitive functions (Dubois and Pillon, 1996; Grace et al., 1998) and deficient plasticity (Ueki et al., 2006; Hasan et al., 2012), like those in Parkinson's disease and schizophrenia, are caused by dopaminergic dysfunction.

The dopaminergic impact on plasticity is complex and depends on dosage, kind of plasticity induction, and receptor subtypes. In humans, the dopaminergic impact on plasticity has been explored by noninvasive brain stimulation techniques, such as transcranial direct current stimulation (tDCS), and paired associative stimulation (PAS). tDCS induces polarity-dependent plasticity of the glutamatergic system not restricted to specific

\footnotetext{
Received Aug. 27, 2013; revised Jan. 11, 2014; accepted Jan. 15, 2014.

Author contributions: W.P. and M.A.N. designed research; S.F. and M.-F.K. performed research; S.F. and M.-F.K. analyzed data; S.F. and M.A.N. wrote the paper.

This work was supported by a grant from the Deutsche Forschungsgemeinschaft (DFG Grant NI 683/6-1).

*M.A.N and M.-F.K. contributed equally to this work.

The authors declare no competing financial interests.

Correspondence should be addressed to Prof. Dr. Michael A. Nitsche, Department of Clinical Neurophysiology, Georg-August-University, Robert-Koch-Str. 40, 37075 Göttingen, Germany. E-mail: mnitsch1@gwdg.de.

DOI:10.1523/JNEUROSCI.3655-13.2014

Copyright $\odot 2014$ the authors $\quad 0270-6474 / 14 / 342744-10 \$ 15.00 / 0$
}

neuronal subgroups (Nitsche et al., 2008; Stagg and Nitsche, 2011). PAS induces neuron-specific glutamatergic plasticity of somatosensory-motor cortical connections, and the direction of plasticity depends on the synchrony of stimulation (Stefan et al., 2000, 2002; Wolters et al., 2003).

Dopamine has a nonlinear dose-dependent effect on neuroplasticity in humans (Monte-Silva et al., 2010; Thirugnanasambandam et al., 2011). Accordingly in animal experiments both insufficient and excessive dopamine impairs cognitive functions, while medium dopaminergic activity improves it (Brozoski et al., 1979; Murphy et al., 1996; Arnsten, 1997). Furthermore, dopamine receptor subtypes have discernable effects on neuroplasticity. D2-like receptor stimulation revealed opposing results on LTP and LTD in animals (Chen et al., 1996; Otani et al., 1998; Manahan-Vaughan and Kulla, 2003), hinting for additional dosage-dependency, which is supported by results of experiments in humans (Monte-Silva et al., 2009). In contrast, D1-like receptor activation enhanced LTP and LTD in animal experiments (Bailey et al., 2000; Gurden et al., 2000; Huang et al., 2004), with the exception of one study, where LTD was reversed into a transient potentiated state (Mockett et al., 2007). Furthermore, the D1 receptor is relevant for learning processes (Piri et al., 2013; Pina and Cunningham, 2014). Because of the close connection between learning and plasticity, a better understanding of dosagedependency of D1 receptor activation on plasticity would be useful in exploring the physiological basis of the D1 receptor's contribution to learning and memory formation (Rioult-Pedotti 
et al., 1998). However, so far, this issue has not been sufficiently explored. Since nonlinear effects of D1 activation on other cognitive processes, like working memory, are well known (Williams and Castner, 2006; Vijayraghavan et al., 2007) and associated with respective effects on cortical activity, similar mechanisms might be involved in how D1 receptors affect plasticity.

We explored dosage-dependent effects of D1-like receptor activation on plasticity of the primary motor cortex induced by tDCS and PAS. Because no selective D1 receptor agonist is available for human use, we blocked D2-like receptors with $400 \mathrm{mg}$ of the D2 receptor antagonist sulpiride, and enhanced global dopaminergic activity with 25, 100, and $200 \mathrm{mg}$ of L-DOPA. We hypothesized that D1-like receptor activation has a nonlinear effect on plasticity.

\section{Materials and Methods}

Subjects. Twelve right-handed, healthy subjects participated in each experiment [ $\mathrm{tDCS}$ experiment: seven males, five females; age, $27.58 \pm 4.01$ years (mean $\pm \mathrm{SD}$ ); PAS experiment: seven males, five females; age, $26.91 \pm 4.23$ years $($ mean $\pm \mathrm{SD})]$. Subjects had no history of acute or chronic medical diseases, had no metallic or electric implants in the body, and did not take medication during the study or $\leq 2$ weeks before participating in the study. Only one occasional smoker (male) participated in the study, and participants denied the use of any recreational drug. Alcohol intake was not allowed $\geq 1 \mathrm{~d}$ before the experiment and coffee on the day of the experiment until the second day. Pregnancy was ruled out by a pregnancy test. Written informed consent was obtained from each subject before participation. The study was approved by the Ethics Committee of the University of Göttingen and conforms to the Declaration of Helsinki.

Monitoring of corticospinal excitability. Corticospinal excitability was monitored by peak-to-peak amplitudes of motor-evoked potentials (MEPs) induced by transcranial magnetic stimulation (TMS) of the motor cortex representation of the right abductor digiti minimi muscle (ADM). Single-pulse TMS generated by a Magstim 200 magnetic stimulator (Magstim) at a frequency of $0.25 \mathrm{~Hz}$ via a figure-eight magnetic coil (diameter of one winding, $70 \mathrm{~mm}$; peak magnetic field, 2.2 tesla) was used to determine optimal coil position, which was defined as the site where stimulation consistently resulted in the largest MEP amplitudes. The coil was held tangentially on the scalp at an angle of $45^{\circ}$ to the midsagittal plane with the handle pointing laterally and posteriorly. Electromyographic (EMG) recording was obtained from the right ADM with $\mathrm{Ag}-\mathrm{AgCl}$ electrodes attached in a belly-tendon montage. Signals were filtered (30 Hz-2 kHz), amplified (Digitimer 360, Digitimer), and then stored on computer via a Power 1401 data acquisition interface (Cambridge Electronic Design). Analysis was performed using Signal Software (Cambridge Electronic Design). TMS intensity was adjusted to elicit baseline MEPs of averaged $1 \mathrm{mV}$ peak-to-peak MEP amplitude and was kept constant for the poststimulation assessment unless adjusted (see below).

Plasticity induction by tDCS (Experiment 1). For tDCS, we used a battery-driven constant current stimulator (NeuroConn) with a maximum output of $4.5 \mathrm{~mA}$. We used two saline-soaked surface sponge electrodes each measuring $7 \times 5 \mathrm{~cm}$ to deliver the current. To achieve a functionally monopolar stimulation over the primary motor cortex, an enlarged return electrode could have been used (Nitsche et al., 2007). To keep the experimental design identical to those of former studies of our group (Kuo et al., 2008; Monte-Silva et al., 2009, 2010; Nitsche et al., 2009; Thirugnanasambandam et al., 2011), and because the size of the return electrode seems to have no impact on resulting motor cortex plasticity (Nitsche et al., 2007), we did not use such a large return electrode. The stimulating electrode was positioned over the cortical representational area of the right $\mathrm{ADM}$ in the motor cortex. The return electrode was positioned above the right supraorbital area. A current strength of $1 \mathrm{~mA}$ was administered for $13 \mathrm{~min}$ for anodal tDCS and $9 \mathrm{~min}$ for cathodal tDCS. This current induces cortical excitability alterations lasting for $\sim 1 \mathrm{~h}$ after the end of stimulation (Nitsche and Paulus, 2001; Nitsche et al., 2003a).
Plasticity induction by PAS (Experiment 2). Peripheral nerve stimulation with a Digitimer D185 stimulator (Digitimer) delivered an electrical pulse to the right ulnar nerve at the wrist level (cathode proximal) with an intensity three times higher than the sensory perceptual threshold (square waveform of $50 \mu$ s duration) combined with single-pulse TMS. Peripheral nerve stimulation was followed by the TMS stimulus with interstimulus intervals of 10 (inhibitory PAS: PAS10) or $25 \mathrm{~ms}$ (excitatory PAS: PAS25). Ninety pairs of stimuli were administered at a frequency of $0.05 \mathrm{~Hz}$ for $30 \mathrm{~min}$, which induces cortical excitability enhancement (PAS25) or reduction (PAS10) for $\sim 1 \mathrm{~h}$ after stimulation (Stefan et al., 2000, 2002; Wolters et al., 2003).

Pharmacological Intervention. Ninety minutes before the start of the plasticity-inducing protocols, the subjects received at each experimental session low $(25 \mathrm{mg})$, medium $(100 \mathrm{mg})$, or high $(200 \mathrm{mg})$ dosages of L-DOPA in fixed combination with the dopamine decarboxylase inhibitor benserazide (one-fourth the dose of L-DOPA) in combination with sulpiride $(400 \mathrm{mg})$, or a placebo medication. At the time of plasticity induction, the drugs have reached peak plasma concentrations and have prominent effects in the CNS (Flöel et al., 2005; Kuo et al., 2008). These dosages of L-DOPA were used since in previous experiments they were shown to induce nonlinear effects on tDCS-induced and PAS-induced plasticity (Monte-Silva et al., 2010; Thirugnanasambandam et al., 2011). To prevent systemic side effects of L-DOPA, such as nausea and vomiting, subjects also received $20 \mathrm{mg}$ of the peripheral-acting dopaminergic antagonist domperidone three times per day for $2 \mathrm{~d}$ before the experiment and also $2 \mathrm{~h}$ before L-DOPA intake. Twenty milligrams of domperidone alone exerts no effects on motor cortical excitability (Grundey et al., 2013).

Experimental procedures. We conducted a double-blinded, randomized, and placebo-controlled study. Experimental sessions (eight sessions per subject; each subject participated in Experiment 1 or 2) were separated by an interval of $\geq 1$ week to avoid interference effects. Each subject was seated on a reclining chair with head and arm support, and was asked to relax, but to keep their eyes open during the course of the experiment. EMG electrodes were placed at the right ADM using a belly-tendon montage. The motor cortex hotspot of the ADM representation was determined by TMS and marked with a skin marker. This was also done for the EMG electrodes to ensure their constant positioning throughout the experiment. Then the TMS intensity that resulted in a MEP amplitude of $\sim 1 \mathrm{mV}$ was identified. At least $25 \mathrm{MEPs}$ were recorded as Baseline 1 with this stimulus intensity. Immediately after the baseline measurement, the participants received placebo medication or a combination of 25,100 , or $200 \mathrm{mg}$ of L-DOPA together with $400 \mathrm{mg}$ of sulpiride. After $90 \mathrm{~min}$, another set of 25 MEPs (Baseline 2) was obtained to check for any druginduced change of MEP amplitudes. If Baseline 2 differed relevantly $(<0.2$ or $>0.2 \mathrm{mV})$ from Baseline 1, TMS intensity was readjusted to produce stable MEP amplitudes of $\sim 1 \mathrm{mV}$ (Baseline 3 ). Then anodal tDCS (13 min), cathodal tDCS (9 min), PAS25, or PAS10 was applied. Following intervention, $25 \mathrm{MEPs}$ were recorded at time points of $0,5,10$, $15,20,25,30,60,90$, and $120 \mathrm{~min}$ on the same day, and then again on the same evening, the next morning, the next afternoon, and the next evening (Fig. 1).

Data analysis and statistics. The individual MEP amplitude means of Baselines 1, 2, and 3 and all time points after plasticity induction were calculated. Postintervention MEP amplitudes were normalized to Baseline 2 only if Baseline 2 did not differ significantly from Baseline 1. Baseline 3 was used for normalization in those subjects where stimulation intensity had been adjusted. Then normalized MEP amplitudes from all subjects were pooled together sessionwise by calculating the grand average across subjects for each condition and time point. After checking for normal distribution (Shapiro-Wilk test), a repeatedmeasures ANOVA was performed for the time bins up to the next evening measurement after tDCS (Experiment 1) and PAS (Experiment 2), with the repeated-measure factors time course, direction of plasticity (anodal and cathodal tDCS, PAS25, and PAS10), drug dosage (25, 100, $200 \mathrm{mg}$ of L-DOPA and placebo), the between-subjects factor stimulation paradigm (tDCS and PAS), and the dependent-variable MEP amplitude. Mauchly's test of sphericity was checked and Greenhouse-Geisser correction applied when necessary. If the ANOVA yielded significant results, 
Premedication

Medication

Postmedication

Plasticity

Induction

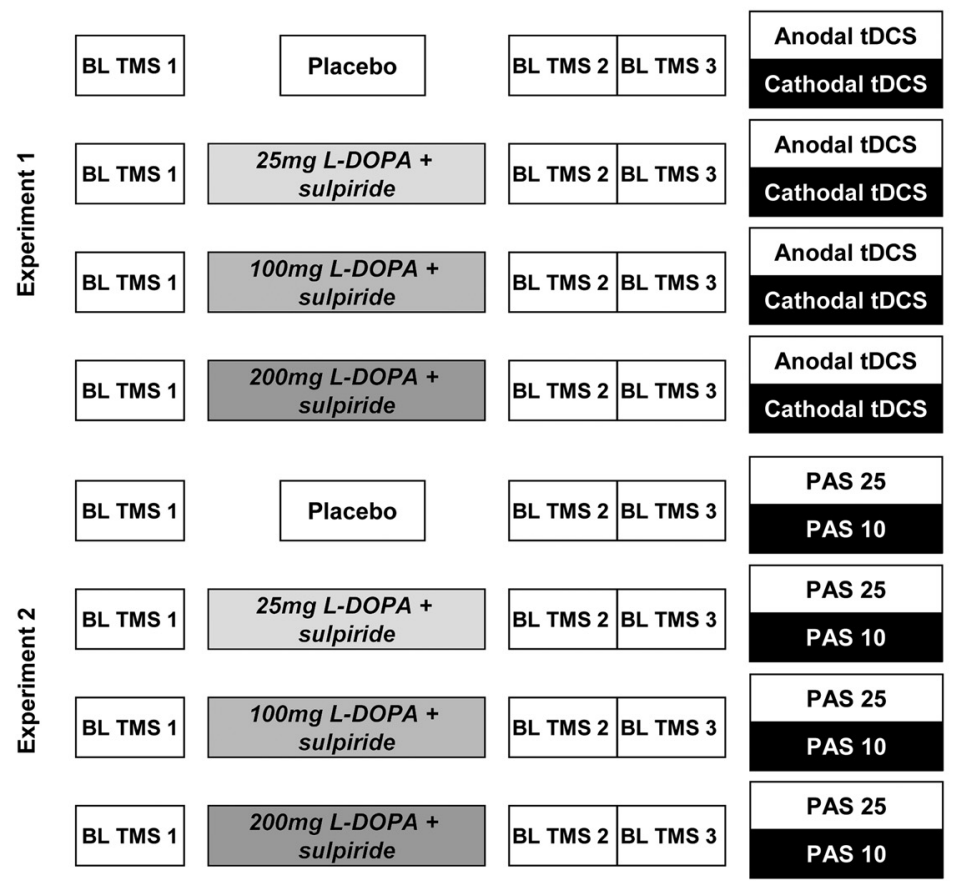

Monitoring motor cortex excitability

\section{MEPs every 5 min for $\mathbf{3 0}$ min then every 30 min until 2 hours, SE, NM, NA, NE after} intervention

\section{MEPs every 5 min for $\mathbf{3 0}$ min then every \\ 30 min until 2 hours, SE, NM, NA, NE after} intervention

\section{MEPs every $\mathbf{5}$ min for $\mathbf{3 0}$ min then every \\ 30 min until 2 hours, SE, NM, NA, NE after intervention}

\section{MEPs every 5 min for $\mathbf{3 0}$ min then every \\ 30 min until 2 hours, SE, NM, NA, NE after intervention}

MEPs every 5 min for 30 min then every
30 min until 2 hours, SE, NM, NA, NE after 30 min until 2 hours, SE, N

MEPs every $5 \mathrm{~min}$ for $\mathbf{3 0} \mathrm{min}$ then every 30 min until 2 hours, SE, NM, NA, NE after intervention

MEPs every $5 \mathrm{~min}$ for $\mathbf{3 0} \mathrm{min}$ then every

30 min until 2 hours, SE, NM, NA, NE after intervention

MEPs every 5 min for $\mathbf{3 0}$ min then every

30 min until 2 hours, SE, NM, NA, NE after intervention

Time course

Figure 1. Course of the experiments. MEPs elicited by single-pulse TMS over the motor hot spot of the right ADM were recorded at $1 \mathrm{mV}$ intensity before drug intake [Baseline 1 (BL TMS 1)]. Ninety minutes after drug intake, Baseline 2 (BL TMS2) was recorded to look for an effect of the drug on cortical excitability. In case of any MEP alterations from Baseline 1, Baseline 3 (BL TMS3) was recorded by adjusting the stimulator output to obtain a mean MEP amplitude of $1 \mathrm{mV}$. Then tDCS (anodal or cathodal) or PAS (excitatory or inhibitory) were administered, immediately followed by MEP after-measurements that covered 120 min. Additional after-measurements were performed at the same evening (SE), and the morning (NM), afternoon (NA), and evening (NE) of the second day following plasticity induction.

post hoc comparisons (paired, two-tailed Student's $t$ tests, $p<0.05$, not adjusted for multiple comparisons) were performed to compare (1) the mean MEP amplitudes at all time points after $\mathrm{tDCS}$ or PAS versus Baseline 2 or 3 and (2) the mean MEP amplitude obtained at a specific time point for the various drug conditions against the respective placebo medication condition. Baselines 1, 2, and $3 \mathrm{MEP}$ amplitudes were compared with test for any drug influence alone on cortical excitability, and to exclude baseline differences between medication/stimulation conditions before plasticity induction. Furthermore, we pooled standardized MEP amplitudes for the first 30 min after plasticity induction, and performed Student's $t$ test (paired samples, two-tailed, $p<0.05$ ) to compare the respective placebo medication conditions with the MEP amplitudes under real stimulation for all plasticity induction protocols.

\section{Results}

One hour after oral intake of $200 \mathrm{mg}$ of L-DOPA together with $400 \mathrm{mg}$ of sulpiride, three subjects experienced mild nausea. One subject vomited. The symptoms diminished after 10-15 min. All subjects completed the respective session. No side effects were reported under both low and medium dosages of the drugs. The remaining subjects tolerated the drugs well.

Peak-to-peak amplitudes of baseline MEPs were not affected by the drugs ( $p \geq 0.05$, Student's paired, two-tailed $t$ test; Table 1 ), and baseline MEP amplitudes and percentage of maximal stimulator output to achieve baseline amplitudes of $\sim 1 \mathrm{mV}$ did not differ between sessions (Student's $t$ test, paired, two-tailed, $p>0.05$; Table 1). The Shapiro-Wilk test indicated that the data were normally distributed (all $p>0.05$ ). The ANOVA revealed significant effects of time course $(\mathrm{df}=14, F=2.706, p=0.001$, $\left.\eta^{2}=0.197\right)$, drug dosage $\times$ direction of plasticity $(\mathrm{df}=3, F=$ $\left.16.900, p<0.001, \eta^{2}=0.606\right)$, direction of plasticity $\times$ time course ( $\left.\mathrm{df}=14, F=3.642, p<0.001, \eta^{2}=0.249\right)$, and drug dosage $\times$ direction of plasticity $\times$ time course $(\mathrm{df}=42, F=$ 3.424, $p<0.001, \eta^{2}=0.237$; Table 2).

\section{Dose-dependent effect of D1 receptor activation on}

tDCS-induced neuroplasticity

Under placebo medication, anodal tDCS increased excitability compared with baseline significantly for $\leq 30 \mathrm{~min}$ after stimulation, while cathodal tDCS significantly decreased excitability for $2 \mathrm{~h}$ (Fig. $2 A, B$ ). Low-dosage L-DOPA abolished any excitability enhancement accomplished by anodal tDCS, compared with the respective baselines. A trend for enhanced MEP amplitudes can be identified for cathodal tDCS under lowdosage L-DOPA relative to baseline values, which resulted in significant differences versus the respective placebo medication condition. Under medium dosage of L-DOPA, anodal tDCS resulted in an excitability enhancement, which was significant 15 and 30 min after stimulation relative to baseline, as shown by the post hoc $t$ tests, but not at the other time points, probably because of relatively large variability of the results. This excitability enhancement did not differ significantly from the respective placebo medication condition. For cathodal tDCS, medium dosage L-DOPA abolished any MEP alterations relative to baseline (Fig. $2 A, B$ ). High-dosage medication resulted in similar effects as low-dosage medication on tDCSgenerated excitability alterations. For anodal tDCS, MEP 
Table 1. Peak-to-peak MEP amplitudes and TMS intensity before and after application of L-DOPA combined with sulpiride

\begin{tabular}{|c|c|c|c|c|c|c|}
\hline L-DOPA plus $400 \mathrm{mg}$ sulpiride & $\begin{array}{l}\text { Baseline } 1 \\
\text { MEP (mV) }\end{array}$ & MSO (\%) & $\begin{array}{l}\text { Baseline 2 } \\
\text { MEP (mV) }\end{array}$ & MSO (\%) & $\begin{array}{l}\text { Baseline } 3 \\
\text { MEP (mV) }\end{array}$ & MSO (\%) \\
\hline Anodal; $25 \mathrm{mg}$ & $1.075 \pm 0.04$ & $47.2 \pm 1.7$ & $1.066 \pm 0.10$ & $47.2 \pm 1.7$ & $1.134 \pm 0.10$ & $46.3 \pm 2.0$ \\
\hline $\mathrm{tDCS} ; 100 \mathrm{mg}$ & $1.154 \pm 0.02$ & $47.1 \pm 1.8$ & $1.077 \pm 0.08$ & $47.1 \pm 1.8$ & $1.091 \pm 0.11$ & $51.3 \pm 5.9$ \\
\hline $\mathrm{tDCS} ; 200 \mathrm{mg}$ & $1.197 \pm 0.10$ & $48.0 \pm 2.1$ & $1.094 \pm 0.10$ & $48.0 \pm 2.1$ & $1.140 \pm 0.12$ & $53.0 \pm 3.5$ \\
\hline Cathodal; $25 \mathrm{mg}$ & $1.143 \pm 0.04$ & $49.0 \pm 1.9$ & $1.097 \pm 0.08$ & $49.0 \pm 1.9$ & $1.031 \pm 0.05$ & $52.0 \pm 3.6$ \\
\hline $\mathrm{tDCS} ; 100 \mathrm{mg}$ & $1.134 \pm 0.10$ & $48.4 \pm 1.8$ & $1.234 \pm 0.05$ & $48.4 \pm 1.8$ & $1.208 \pm 0.01$ & $49.0 \pm 2.5$ \\
\hline $\mathrm{tDCS} ; 200 \mathrm{mg}$ & $1.114 \pm 0.03$ & $48.0 \pm 2.1$ & $1.054 \pm 0.05$ & $48.0 \pm 2.1$ & $1.047 \pm 0.10$ & $55.0 \pm 3.5$ \\
\hline PAS25; $25 \mathrm{mg}$ & $1.042 \pm 0.03$ & $42.4 \pm 1.6$ & $1.140 \pm 0.05$ & $42.4 \pm 1.6$ & $1.140 \pm 0.05$ & $42.4 \pm 1.6$ \\
\hline PAS25; $100 \mathrm{mg}$ & $1.165 \pm 0.03$ & $42.0 \pm 1.8$ & $1.070 \pm 0.06$ & $42.0 \pm 1.8$ & $1.105 \pm 0.02$ & $42.0 \pm 2.7$ \\
\hline PAS25; $200 \mathrm{mg}$ & $1.144 \pm 0.03$ & $44.0 \pm 1.7$ & $1.353 \pm 0.10$ & $44.0 \pm 1.7$ & $1.121 \pm 0.04$ & $47.0 \pm 2.9$ \\
\hline PAS10; $25 \mathrm{mg}$ & $1.108 \pm 0.04$ & $44.0 \pm 2.2$ & $1.038 \pm 0.04$ & $44.0 \pm 2.2$ & $1.101 \pm 0.00$ & $47.0 \pm 4.6$ \\
\hline PAS10; $100 \mathrm{mg}$ & $1.094 \pm 0.10$ & $44.0 \pm 1.9$ & $1.032 \pm 0.11$ & $44.0 \pm 1.9$ & $1.105 \pm 0.07$ & $44.0 \pm 1.6$ \\
\hline PAS10; $200 \mathrm{mg}$ & $1.121 \pm 0.04$ & $42.3 \pm 2.4$ & $0.996 \pm 0.13$ & $42.3 \pm 2.4$ & $1.104 \pm 0.03$ & $43.0 \pm 6.1$ \\
\hline
\end{tabular}

Shown are the mean $+1-$ standard error of mean (SEM) of MEP amplitudes and stimulation intensities [percentage of maximum stimulator output (MSO)] of Baselines 1, 2, and 3. There was no significant difference between these parameters across the different conditions (Student's $t$ test, paired, 2-tailed, $p>0.05$ ).

Table 2. Results of the ANOVA conducted for tDCS and PAS

\begin{tabular}{lrrrr}
\hline & df & Fvalue & $p$ value & $n^{2}$ \\
\hline Stimulation & 1 & 0.077 & 0.786 & 0.007 \\
Dosage & 3 & 0.075 & 0.973 & 0.007 \\
Polarity & 1 & 4.114 & 0.067 & 0.272 \\
Time course & 14 & 2.706 & $0.001^{*}$ & 0.197 \\
Stimulation $\times$ dosage & 3 & 1.014 & 0.399 & 0.084 \\
Stimulation $\times$ polarity & 1 & 0.761 & 0.402 & 0.065 \\
Dosage $\times$ polarity & 3 & 16.900 & $<0.001^{*}$ & 0.606 \\
Stimulation $\times$ dosage $\times$ polarity & 3 & 0.249 & 0.862 & 0.022 \\
Stimulation $\times$ time course & 14 & 0.374 & 0.980 & 0.033 \\
Dosage $\times$ time course & 42 & 1.300 & 0.105 & 0.106 \\
Stimulation $\times$ dosage $\times$ time & 42 & 0.663 & 0.949 & 0.057 \\
$\quad$ course & & & & \\
Polarity $\times$ time course & 14 & 3.642 & $<0.001^{*}$ & 0.249 \\
Stimulation $\times$ polarity $\times$ time & 14 & 0.420 & 0.967 & 0.037 \\
$\quad$ course & & & & \\
Dosage $\times$ polarity $\times$ time course & 42 & 3.424 & $<0.001^{*}$ & 0.237 \\
Stimulation $\times$ dosage $\times$ polarity $\times$ & 42 & 0.538 & 0.992 & 0.047 \\
$\quad$ time course & & & & \\
S & & & &
\end{tabular}

The ANOVA encompasses the time course of the MEP measures up to evening after stimulation. Asterisks indicate significant results $(p<0.05)$. df, Degrees of freedom; $\mathrm{n}^{2}$, partial eta squared (measure of effect size).

amplitudes did not differ from baseline values, but were significantly reduced relative to placebo medication $0,5,10,20$, and 120 min after tDCS (Student's $t$ test, paired, two-tailed, $p \leq 0.05)$. For cathodal tDCS, excitability was trendwise enhanced relative to baseline, and significantly different from cathodal tDCS-generated excitability reductions under placebo medication (Fig. $2 A, B$ ). For anodal tDCS, pooled MEP amplitudes $60 \mathrm{~min}$ after stimulation were significantly reduced compared with placebo medication under both lowdosage and high-dosage L-DOPA, while no reduction was observed under medium dosage (Fig. 4A). For cathodal tDCS, the conversion into excitation under low and high dose, and the reduction of the excitability diminution under medium dose, were significant (see Fig. 4A). No significant effects where found on the second day (see Fig. $4 B$ ). In summary, L-DOPA combined with sulpiride dosage-dependently modified tDCS-induced excitability changes depending on stimulation polarity: whereas low and high dosages of L-DOPA together with sulpiride diminished and abolished anodal tDCS-induced facilitatory neuroplasticity, medium dosage preserved it; the cathodal tDCS-induced aftereffects were converted into facilitation under low and high dosage, and were abolished under the medium dosage.

\section{Dose-dependent effect of $\mathrm{D} 1$ receptor activation on PAS-induced neuroplasticity}

Under placebo medication, PAS25 increased excitability significantly compared with baseline until $90 \mathrm{~min}$, whereas PAS10 decreased excitability for $1 \mathrm{~h}$ (see Fig. $3 A, B$ ). For excitatory PAS, low-dosage L-DOPA did not result in significant excitability alterations relative to baseline. However, inhibitory PAS enhanced MEP amplitudes significantly relative to baseline values $20 \mathrm{~min}$ after PAS. MEP amplitudes differed significantly from those under placebo medication, as shown by the results of the post hoc tests. Under medium-dosage L-DOPA, excitatory PAS resulted in a significant excitability enhancement versus baseline values for $\leq 30$ min after stimulation, which did not differ from PAS25 effects under placebo medication. In contrast, MEP amplitudes after PAS10 were only significantly different from baseline values after $15 \mathrm{~min}$, resulting in respective significant differences in relation to the placebo medication condition (Fig. $3 A, B$ ). Highdosage L-DOPA prevented aftereffects of PAS25 and PAS10 relative to baseline excitability; consequently MEP amplitudes differed significantly from those under placebo medication (Fig. $3 A, B)$. Pooled MEP values for the first $60 \mathrm{~min}$ after inhibitory PAS were all significantly larger compared with the placebo medication condition, whereas for PAS25, MEP amplitudes were significantly less enhanced compared with placebo medication. However, in the latter condition, medium dosage of L-DOPA resulted in a clear enhancement of MEP amplitudes in relation to baseline (Fig. 4A). The effect of L-DOPA on PAS25 was still significant compared with placebo on the second day, however less clear than immediately after stimulation (Fig. 4B). To summarize the effect of D1 receptor activation by L-DOPA combined with sulpiride on PAS-induced plasticity, a dosage-dependent effect was observed depending on the type of stimulation: whereas low and high dose of L-DOPA abolished PAS25-induced neuroplasticity, medium dosage preserved it. On the other hand, the PAS10-induced aftereffects were abolished or trendwise facilitated under all dosages.

\section{Discussion}

The results show a nonlinear dosage-dependency of D1-like receptor activation on motor cortex plasticity. For facilitatory tDCS and excitatory PAS, low and high activation of D1-like receptors impaired plasticity, while moderate activation preserved it. For excitability-diminishing plasticity, D1-like receptor activation reversed all aftereffects of PAS trendwise into facilitation, whereas for tDCS, high and trendwise low D1-like receptor activation converted the excitability diminution into facilitation, while under medium dosage the inhibitory aftereffects were abolished. 

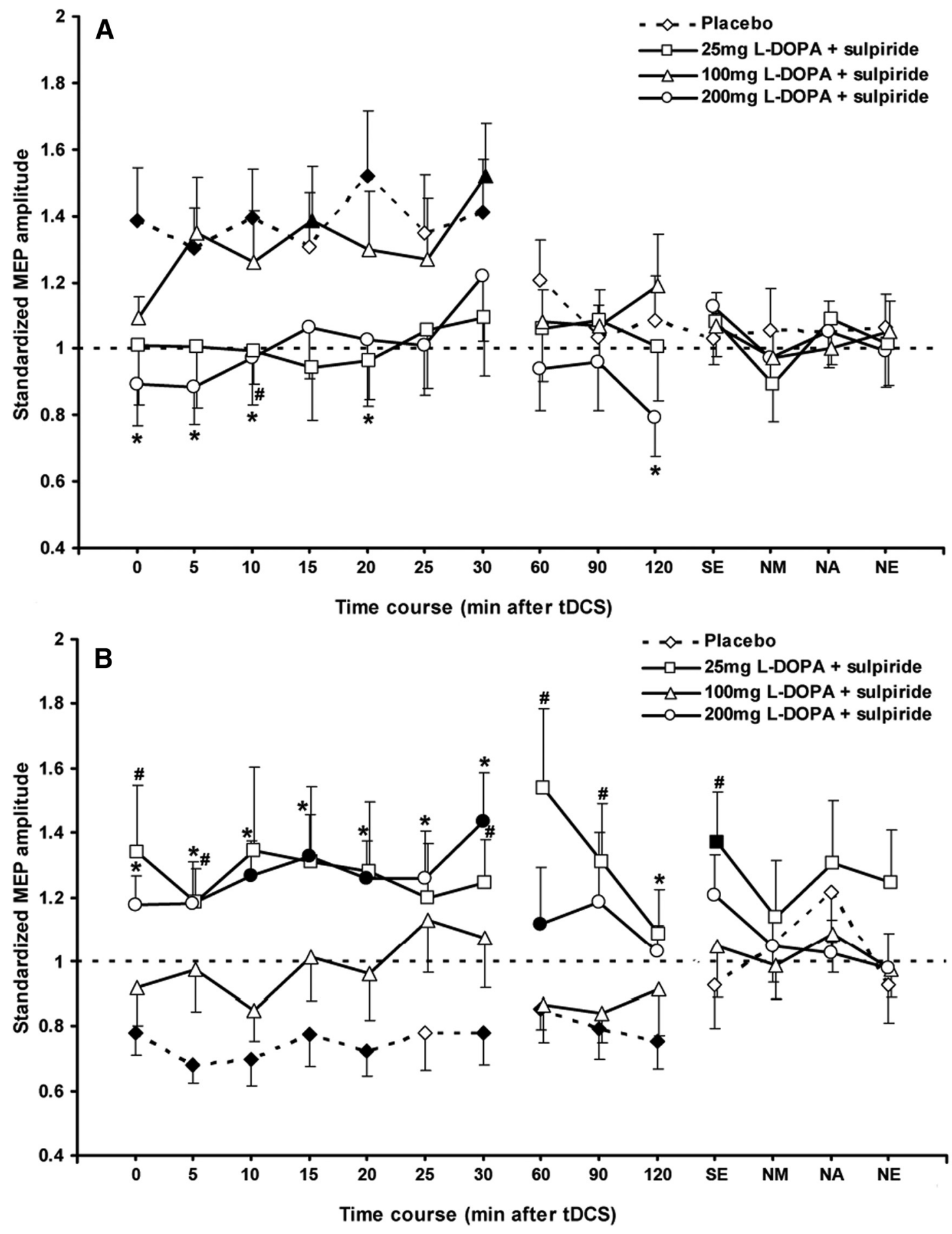

Figure 2. Dose-dependent effect of D1-like receptor activation on plasticity induced by anodal and cathodal tDCS (Experiment 1). The $x$-axis displays the time points (in minutes) of after-measurements during the experiment. MEP amplitudes standardized to the corresponding baseline values (mean \pm SEM) are plotted on the $y$-axis. The graphs show that under placebo medication, anodal tDCS induces an excitability enhancement lasting for $\sim 30 \mathrm{~min}$, whereas cathodal tDCS diminishes excitability for $>1 \mathrm{~h}$ following stimulation. $A$, Low-dose $(25 \mathrm{mg})$ and high-dose (200 mg) L-DOPA impaired and abolished the aftereffects of anodal tDCS respectively, while medium-dose $(100 \mathrm{mg})$ L-DOPA together with sulpiride preserved the anodal tDCS-generated aftereffects. $\boldsymbol{B}$, Low-dose and high-dose L-DOPA resulted in trendwise facilitation of the cathodal tDCS-generated aftereffects, while under medium dose the aftereffects were abolished. Filled symbols indicate statistically significant deviations of the post-tDCS MEP values compared

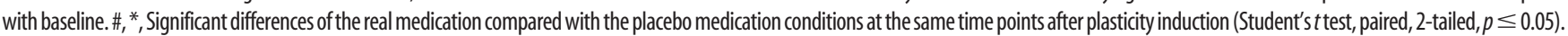
SE, Same evening; NM, next morning; NA, next afternoon; NE, next evening. Error bars show SE of mean (SEM).\#, 25 mg of L-DOPA. * 200 mg of L-DOPA.

D1-like receptor stimulation effects on excitatory stimulation paradigms

D1-like receptor activation causes a dose-dependent inverted U-shaped effect on LTP-like plasticity induced by anodal tDCS and PAS25. Too much or too little D1-receptor activation by
L-DOPA under D2 receptor block suppresses the induction of plasticity, while under medium D1-like receptor activation plasticity was preserved. These effects of D1-like receptor activity on LTP-like plasticity extend previous results of our group. Here D2 receptor block alone abolished facilitatory tDCS-induced plastic- 

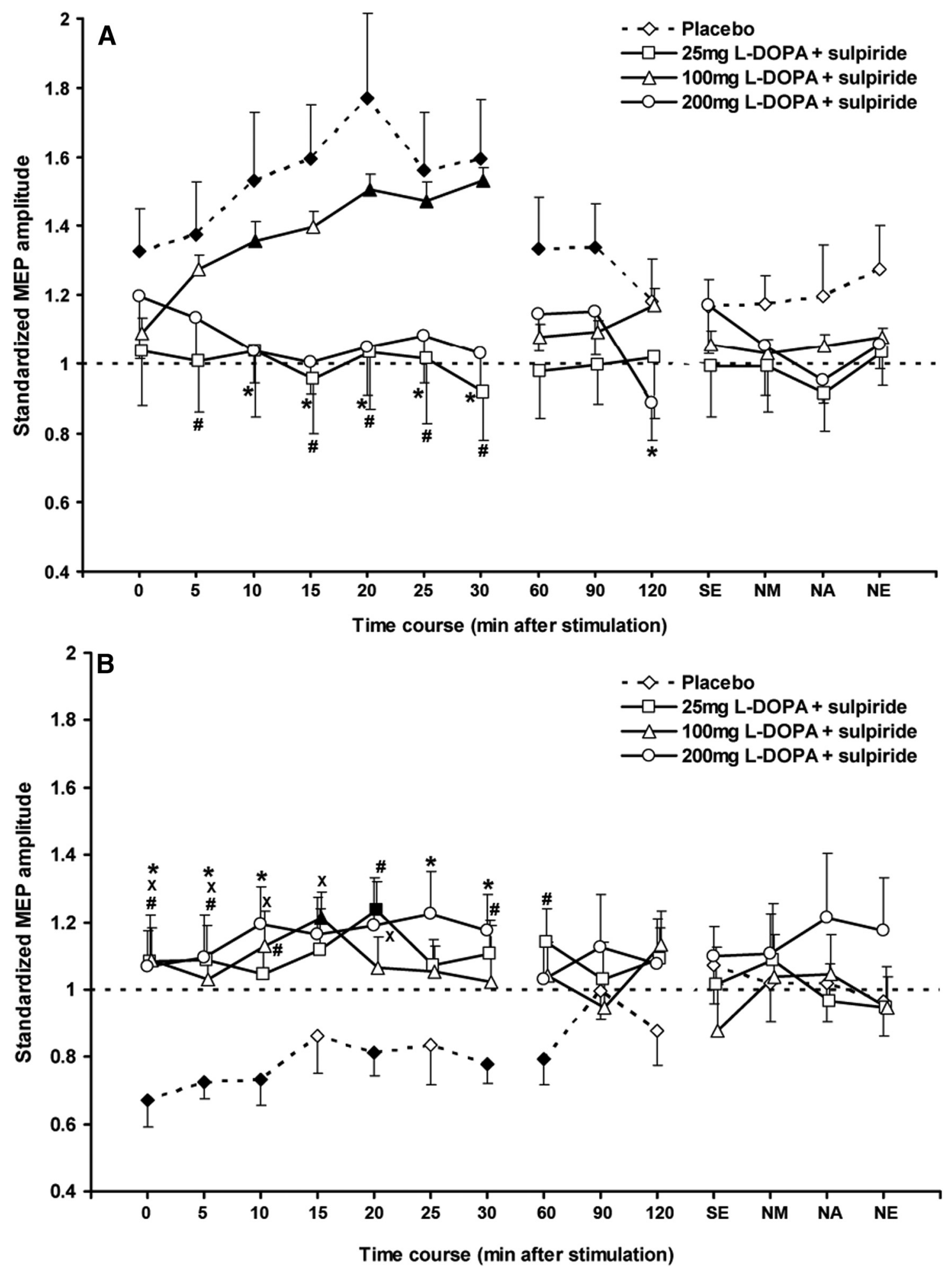

Figure 3. Dose-dependent effects of D1-like receptor activation on plasticity induced by PAS25 and PAS10 (Experiment 2). The $x$-axis displays the time points (in minutes) of after-measurements during the experiment. MEP amplitudes standardized to the corresponding baseline values (mean \pm SEM) are plotted on the $y$-axis. The graphs show that under placebo medication, excitatory PAS (PAS25) induces an excitability enhancement lasting for $\sim 60 \mathrm{~min}$, whereas inhibitory PAS (PAS10) diminishes excitability for $>1 \mathrm{~h}$ following stimulation. A, Low-dose (25 mg) and high-dose (200 mg) L-DOPA applied together with sulpiride abolish the aftereffects of PAS25, whereas medium-dose (100 mg) L-DOPA with sulpiride preserved it. $B$, Low-dose ( $25 \mathrm{mg}$ ), medium-dose ( $100 \mathrm{mg})$, and high-dose $(200 \mathrm{mg}$ ) L-DOPA with sulpiride trendwise converted the PAS10 aftereffects into facilitation. Filled symbols indicate statistically significant deviations of the post-PAS MEP values compared with baseline. $\#, X,{ }^{*}$, Significant differences of the real medication compared with the placebo medication conditions at the same time points after plasticity induction (Student's $t$ test, paired, 2-tailed, $p \leq 0.05)$. SE, Same evening; NM, next morning; NA, next afternoon; NE, next evening. Error bars show SEM. \#, 25 mg of L-DOPA. X, 100 mg of L-DOPA. *, 200 mg of L-DOPA. 


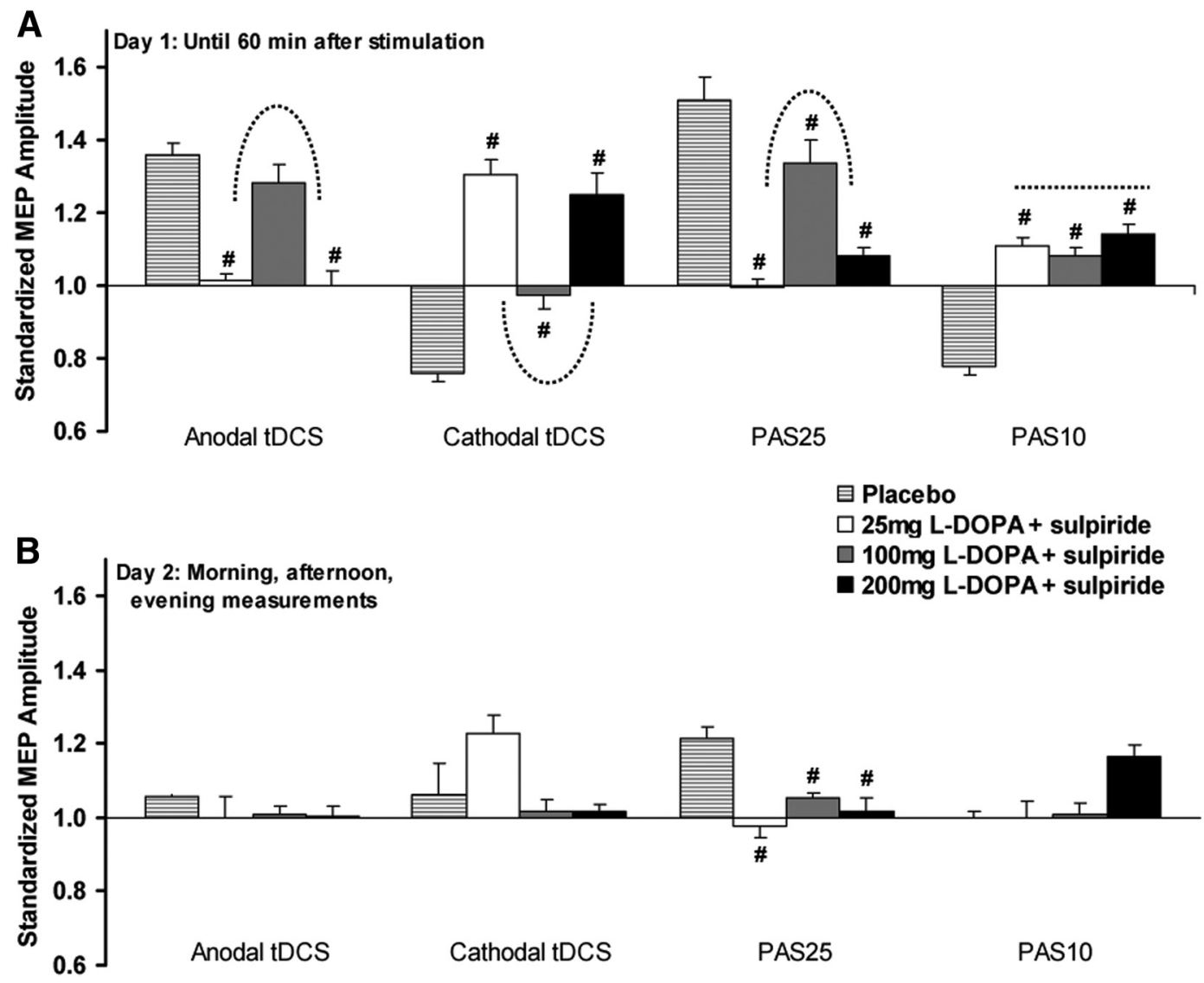

Figure 4. Dose-dependent effects of D1 receptor activation on plasticity induced by tDCS and PAS. $A, B$, Shown are baseline-standardized MEP amplitudes \pm SEM pooled for 60 min after anodal/cathodal tDCS and PAS25/PAS10 $(\boldsymbol{A})$ and the second-day measurements $(\boldsymbol{B})$. D1 receptor activation by L-DOPA under D2 receptor block by sulpiride has inverted U-shaped effects on neuroplasticity induced by anodal tDCS, cathodal tDCS, and excitatory PAS. High-dose or low-dose L-DOPA with sulpiride impaired, abolished, or reversed plasticity. No dose-dependent alterations on inhibitory PAS-induced aftereffects were observed $(\boldsymbol{A})$. The aftereffect of PAS25 was still significant on the second day $(\boldsymbol{B})$.\#, Significant differences of the real medication compared with placebo medication (Student's $t$ test, paired, 2-tailed, $p \leq 0.05$ ).

ity, which was however re-established by a medium dose (100 mg) of L-DOPA (Nitsche et al., 2006, 2009). The results of the present study suggest that an optimal level of D1-like receptor activation is required for the induction of LTP-like plasticity in the human motor cortex. This correlates with findings from single-cell recordings of the prefrontal cortex of monkeys (Vijayraghavan et al., 2007), and cognitive task performance in awake behaving animals (Cai and Arnsten, 1997; Zahrt et al., 1997; Granon et al., 2000). Vijayraghan and colleagues observed that the same group of PFC neurons dose-dependently respond to a D1 receptor agonist (SKP81297) during the delay period of a spatial working memory task. Low (10 nA) and high dosage (40 nA) marginally reduced neuronal firing rates and significantly suppressed delay-related activity of neurons that fire to preferred directions respectively, whereas moderate levels ( $15 \mathrm{nA})$ led to an enhancement in spatial tuning of mnemonic activity. Behaviorally, performance was improved by relatively low doses of selective D1 agonists, but larger doses impaired performance (Cai and Arnsten, 1997; Zahrt et al., 1997). The results of the present study imply that D1 receptor activation has similar nonlinear dosagedependent effects on plasticity, which might affect learning and memory formation.

With regard to involved mechanisms, we can only speculate at present. However, three facts suggest that the glutamatergic and GABAergic systems are relevant (Durstewitz and Seamans, 2008): (1) tDCS as well as PAS induce plasticity of glutamatergic synapses (Stefan et al., 2002; Nitsche et al., 2003b, 2004; Wolters et al., 2003); (2) tDCS alters GABAergic activity (Stagg et al., 2009); and (3) D1 and D2 receptors have a specific impact on NMDA and GABAergic receptors. D2 receptors inhibit glutamatergic and GABAergic activity (Seamans and Yang, 2004) such that their block by sulpiride will enhance activity of both systems. D1 receptors enhance glutamatergic and GABAergic activity. However, only in highly active neurons is the impact on glutamate larger than that on GABA (Seamans and Yang, 2004). Thus, for low-dosage L-DOPA under sulpiride, synergistic strengthening of GABAergic activity by $\mathrm{D} 2$ receptor block and D1 receptor enhancement might abolish glutamatergic tDCS-induced and PAS-induced plasticity. Alternatively, the activation of presynaptic D1 autoreceptors, which reduce dopamine release in animal experiments, might have abolished plasticity (Pennartz et al., 1992; Momiyama et al., 1996), or the minor D1 receptor activation might not have been sufficient to overcome the plasticityabolishing effect of D2 receptor block accomplished by sulpiride (Nitsche et al., 2006).

For the medium dosage, enhanced D1-like receptor activation preserved the excitatory effect of anodal tDCS and PAS25. This is probably due to the predominant NMDA receptor-enhancing effect of optimal D1-like receptor stimulation (Seamans and Yang, 2004). The reason high-dosage L-DOPA abolished both the effects of anodal tDCS and PAS25 may be traced to (1) excessive activation of glutamatergic receptors, which can activate hyper- 
polarizing potassium channels (Misonou et al., 2004) and thus be detrimental for LTP induction; or to (2) D1-induced enhancement of GABA-evoked currents (Flores-Hernandez et al., 2000).

\section{D1-like receptor stimulation effects on inhibitory stimulation paradigms}

The effect of D1-like receptor activation on LTD-like plasticity, similar to the effect on LTP-like plasticity, follows an inverted U-shaped curve, but not in such a clear, unambiguous way. D1 receptor activation dose-dependently abolished or trendwise converted LTD-like plasticity. With respect to the medium dosage, these effects are not in full accordance with those found in a previous study, where $100 \mathrm{mg}$ of L-DOPA combined with sulpiride only trendwise reduced the effects of cathodal tDCS, and had no impact on PAS10-generated plasticity (Nitsche et al., 2009). This might be due to differences in baseline dopamine concentration between subjects (Cools and D'Esposito, 2011) or to other factors, like genetic polymorphisms. However, the results of the present study agree in principle with those of an animal slice experiment, where LTD was transiently converted into a potentiation via D1-like receptor activation (Mockett et al., 2007).

With regard to putative mechanisms, again predominant GABA receptor activation or activation of D1 autoreceptors under low-dosage medication might have abolished plasticity induction. For the medium and high L-DOPA dosages, a shift to predominant glutamatergic receptor activation accomplished by more efficient D1 receptor activation might have resulted in intracellular calcium concentrations too large to elicit LTD-like plasticity, but too low to induce LTP-like plasticity (Lisman, 2001). Generally, D2 receptor block might have favored a D1-like receptor "biased" system, which favors facilitation. This is in accordance with electrophysiological recordings from D2 receptordeficient mice, where conversion of LTD to LTP occurs (Cepeda et al., 2001). However, future studies should explore mechanisms of action more directly.

\section{General remarks}

For tDCS and PAS, D1 receptor activation has a specific effect on plasticity, which is discernable from that of D2 (Monte-Silva et al., 2009) and global dopamine activation (Monte-Silva et al., 2010; Thirugnanasambandam et al., 2011). Neither D2 nor D1 activation alone can explain all global dopamine effects. A focusing effect on facilitatory plasticity (i.e., a strengthening of synaptic subgroup-specific LTP-like plasticity, but conversion of nonspecific LTP-like plasticity) was only accomplished by medium-dosage global dopaminergic stimulation, but not by selective D1-like or D2-like activation. Here, synergistic activities of the respective receptor subtypes might be needed. The nonlinear effects of D1 receptor stimulation on facilitatory plasticity might help explain its impact on cognitive performance, especially with regard to learning and memory formation. Low and high receptor activation might reduce performance via its compromising effect on plasticity, whereas optimal activation should preserve it. This hypothesis awaits testing in future studies. However, respective nonlinear effects of D1 receptor stimulation have been demonstrated for their impact on working memory and acute neuronal activity. Targeting the D1 receptors for improving cognitive functions could be an alternative treatment for Parkinson's disease (Cools, 2006), where dopamine depletion and excess cause deficits (Gotham et al., 1988). Likewise, in schizophrenia, where a relationship between prefrontal dopamine function and the integrity of working memory has been proposed, targeting D1 receptors might be relevant (Goldman-Rakic et al., 2004). Some limitations of our study should be mentioned. With regard to the mechanistic explanation of the results, the proposed modes of action are speculative at present. Furthermore, the indirect approach we had to choose for the activation of $\mathrm{D} 1$ receptors bears the risk that the activation of receptors other than D1 receptors (e.g., D3, D4, and D5 receptors) by L-DOPA contributed to the results. A primary involvement of $\mathrm{D} 3$ receptors is improbable. The predominant D3 receptor agonist ropinirole had different effects in another study (Monte-Silva et al., 2009), and not only D2, but also D3 receptors are blocked by sulpiride. Furthermore, individual differences in baseline dopamine level might limit comparability of results obtained with different subject groups. This might explain minor deviations of the results of the present study, compared with previous ones. However, our subject group was fairly homogenous and demographic characteristics were comparable to those of the subjects in the other studies (Kuo et al., 2008; Nitsche et al., 2009; Monte-Silva et al., 2010; Thirugnanasambandam et al., 2011). The results of the present study might not, however, be completely transferable to groups with other demographic characteristics. In older subjects, baseline dopamine is lower, which might affect the dosage-dependency of the effects (Floel et al., 2008). Blinding might have been compromised in four subjects suffering from mild nausea or vomiting after high-dose L-DOPA in single sessions. Multiple sessions, blinded tDCS and PAS protocols, medication, and identical aftermeasurement durations in all conditions should have guaranteed blinding of most of the participants. Finally, we did not obtain drug plasma levels, which would have enabled exploration of dosage-dependent and gene polymorphism-dependent effects of the medication in greater detail (Witte and Flöel, 2012; Witte et al., 2012; Kristin et al., 2013). Further studies are needed to explore the specific contribution of D1-like receptor stimulation on cognition in humans. Given the prominent effects of D1-like receptor activation on plasticity in humans, an important impact of this receptor on cognition in humans can be expected.

\section{References}

Arnsten AFT (1997) Catecholamine regulation of the prefrontal cortex. J Psychopharmacology 11:151-162. CrossRef

Bailey CH, Giustetto M, Huang YY, Hawkins RD, Kandel ER (2000) Is heterosynaptic modulation essential for stabilizing Hebbian plasticity and memory? Nat Rev Neurosci 1:11-20. CrossRef Medline

Brozoski TJ, Brown RM, Rosvold HE, Goldman PS (1979) Cognitive deficit caused by regional depletion of dopamine in prefrontal cortex of rhesus monkey. Science 205:929-932. CrossRef Medline

Cai JX, Arnsten AF (1997) Dose-dependent effects of the dopamine D1 receptor agonists A77636 or SKF81297 on spatial working memory in aged monkeys. J Pharmacol Exp Ther 283:183-189. Medline

Cepeda C, Hurst RS, Altemus KL, Flores-Hernández J, Calvert CR, Jokel ES, Grandy DK, Low MJ, Rubinstein M, Ariano MA, Levine MS (2001) Facilitated glutamatergic transmission in the striatum of D2 dopamine receptor-deficient mice. J Neurophysiol 85:659-670. Medline

Chen Z, Ito K, Fujii S, Miura M, Furuse H, Sasaki H, Kaneko K, Kato H, Miyakawa H (1996) Roles of dopamine receptors in long-term depression: enhancement via D1 receptors and inhibition via D2 receptors. Receptors Channels 4:1-8. Medline

Cools R (2006) Dopaminergic modulation of cognitive functionimplications for L-DOPA treatment in Parkinson's disease. Neurosci Biobehav Rev 30:1-23. CrossRef Medline

Cools R, D’Esposito M (2011) Inverted-U-shaped dopamine actions on human working memory and cognitive control. Biol Psychiatry 69:e113e125. CrossRef Medline

Dubois B, Pillon B (1996) Cognitive deficits in Parkinson's disease. J Neurology 244:2-8. CrossRef

Durstewitz D, Seamans JK (2008) The dual-state theory of prefrontal cortex dopamine function with relevance to catechol-O-methyltransferase ge- 
notypes and schizophrenia. Biol Psychiatry 64:739-749. CrossRef Medline

Flöel A, Breitenstein C, Hummel F, Celnik P, Gingert C, Sawaki L, Knecht S, Cohen LG (2005) Dopaminergic influences on formation of a motor memory. Ann Neurol 58:121-130. CrossRef Medline

Floel A, Vomhof P, Lorenzen A, Roesser N, Breitenstein C, Knecht S (2008) Levodopa improves skilled hand functions in the elderly. Eur J Neurosci 27:1301-1307. CrossRef Medline

Floresco SB, Phillips AG (2001) Delay-dependent modulation of memory retrieval by infusion of a dopamine $\mathrm{D}_{1}$ agonist into the rat medial prefrontal cortex. Behav Neurosci 115:934-939. CrossRef Medline

Flores-Hernandez J, Hernandez S, Snyder GL, Yan Z, Fienberg AA, Moss SJ, Greengard P, Surmeier DJ (2000) D1 dopamine receptor activation reduces $\mathrm{GABA}(\mathrm{A})$ receptor currents in neostriatal neurons through a PKA/DARPP-32/PP1 signaling cascade. J Neurophysiol 83:2996-3004. Medline

Goldman-Rakic PS, Castner SA, Svensson TH, Siever LJ, Williams GV (2004) Targeting the dopamine D1 receptor in schizophrenia: insights for cognitive dysfunction. Psychopharmacology 174:3-16. Medline

Gotham AM, Brown RG, Marsden CD (1988) 'Frontal' cognitive function in patients with Parkinson's disease 'on' and 'off levodopa. Brain 111: 299-321. CrossRef Medline

Grace AA, Gerfen CR, Aston-Jones G (1998) Catecholamines in the central nervous system. Overview. Adv Pharmacol 42:655-670. CrossRef Medline

Granon S, Passetti F, Thomas KL, Dalley JW, Everitt BJ, Robbins TW (2000) Enhanced and impaired attentional performance after infusion of D1 dopaminergic receptor agents into rat prefrontal cortex. J Neurosci 20: 1208-1215. Medline

Grundey J, Freznosa S, Klinker F, Lang N, Paulus W, Nitsche MA (2013) Cortical excitability in smoking and not smoking individuals with and without nicotine. Psychopharmacology 229:653-664. CrossRef Medline

Gurden H, Takita M, Jay TM (2000) Essential role of D1 but not D2 receptors in the NMDA receptor-dependent long-term potentiation at hippocampal-prefrontal cortex synapses in vivo. J Neurosci 20:RC106. Medline

Hasan A, Nitsche MA, Herrmann M, Schneider-Axmann T, Marshall L, Gruber O, Falkai P, Wobrock T (2012) Impaired long-term depression in schizophrenia: a cathodal tDCS pilot study. Brain Stimul 5:475-483. CrossRef Medline

Huang YY, Simpson E, Kellendonk C, Kandel ER (2004) Genetic evidence for the bidirectional modulation of synaptic plasticity in the prefrontal cortex by D1 receptors. Proc Natl Acad Sci U S A 101:3236-3241. CrossRef Medline

Knecht S, Breitenstein C, Bushuven S, Wailke S, Kamping S, Flöel A, Zwitserlood P, Ringelstein EB (2004) Levodopa: faster and better word learning in normal humans. Ann Neurol 56:20-26. CrossRef Medline

Kristin MP-F, Brian M, Daniel A, Babak S, Steven CC (2013) Genetic variation in the human brain dopamine system influences motor learning and its modulation by L-Dopa. PLoS One 8:e61197. CrossRef Medline

Kuo MF, Paulus W, Nitsche MA (2008) Boosting focally-induced brain plasticity by dopamine. Cereb Cortex 18:648-651. CrossRef Medline

Lisman JE (2001) Three Ca2+ levels affect plasticity differently: the LTP zone, the LTD zone and no man's land. J Physiol 532:285. CrossRef Medline

Manahan-Vaughan D, Kulla A (2003) Regulation of depotentiation and long-term potentiation in the dentate gyrus of freely moving rats by dopamine D2-like receptors. Cereb Cortex 13:123-135. CrossRef Medline

Misonou H, Mohapatra DP, Park EW, Leung V, Zhen D, Misonou K, Anderson AE, Trimmer JS (2004) Regulation of ion channel localization and phosphorylation by neuronal activity. Nat Neurosci 7:711-718. CrossRef Medline

Mockett BG, Guévremont D, Williams JM, Abraham WC (2007) Dopamine D1/D5 receptor activation reverses NMDA receptor-dependent longterm depression in rat hippocampus. J Neurosci 27:2918-2926. CrossRef Medline

Momiyama T, Sim JA, Brown DA (1996) Dopamine D1-like receptormediated presynaptic inhibition of excitatory transmission onto rat magnocellular basal forebrain neurones. J Physiol 495:97-106. Medline

Monte-Silva K, Kuo MF, Thirugnanasambandam N, Liebetanz D, Paulus W, Nitsche MA (2009) Dose-dependent inverted U-shaped effect of dopa- mine (D2-like) receptor activation on focal and nonfocal plasticity in humans. J Neurosci 29:6124-6131. CrossRef Medline

Monte-Silva K, Liebetanz D, Grundey J, Paulus W, Nitsche MA (2010) Dosage-dependent non-linear effect of L-dopa on human motor cortex plasticity. J Physiol 588:3415-3424. CrossRef Medline

Murphy BL, Arnsten AF, Goldman-Rakic PS, Roth RH (1996) Increased dopamine turnover in the prefrontal cortex impairs spatial working memory performance in rats and monkeys. Proc Natl Acad Sci U S A 93:1325-1329. CrossRef Medline

Nitsche MA, Paulus W (2001) Sustained excitability elevations induced by transcranial DC motor cortex stimulation in humans. Neurology 57: 1899-1901. CrossRef Medline

Nitsche MA, Nitsche MS, Klein CC, Tergau F, Rothwell JC, Paulus W (2003a) Level of action of cathodal DC polarisation induced inhibition of the human motor cortex. Clin Neurophysiol 114:600-604. CrossRef Medline

Nitsche MA, Fricke K, Henschke U, Schlitterlau A, Liebetanz D, Lang N, Henning S, Tergau F, Paulus W (2003b) Pharmacological modulation of cortical excitability shifts induced by transcranial direct current stimulation in humans. J Physiol 553:293-301. CrossRef Medline

Nitsche MA, Liebetanz D, Schlitterlau A, Henschke U, Fricke K, Frommann K, Lang N, Henning S, Paulus W, Tergau F (2004) GABAergic modulation of DC stimulation-induced motor cortex excitability shifts in humans. Eur J Neurosci 19:2720-2726. CrossRef Medline

Nitsche MA, Lampe C, Antal A, Liebetanz D, Lang N, Tergau F, Paulus W (2006) Dopaminergic modulation of long-lasting direct current-induced cortical excitability changes in the human motor cortex. Eur J Neurosci 23:1651-1657. CrossRef Medline

Nitsche MA, Doemkes S, Karaköse T, Antal A, Liebetanz D, Lang N, Tergau F, Paulus W (2007) Shaping the effects of transcranial direct current stimulation of the human motor cortex. J Neurophysiol 97:3109-3117. CrossRef Medline

Nitsche MA, Cohen LG, Wassermann EM, Priori A, Lang N, Antal A, Paulus W, Hummel F, Boggio PS, Fregni F, Pascual-Leone A (2008) Transcranial direct current stimulation: state of the art 2008. Brain Stimul 1:206223. CrossRef Medline

Nitsche MA, Kuo MF, Grosch J, Bergner C, Monte-Silva K, Paulus W (2009) D1-receptor impact on neuroplasticity in humans. J Neurosci 29:2648 2653. CrossRef Medline

Otani S, Blond O, Desce JM, Crépel F (1998) Dopamine facilitates longterm depression of glutamatergic transmission in rat prefrontal cortex. Neuroscience 85:669-676. CrossRef Medline

Pennartz CM, Dolleman-Van der Weel MJ, Kitai ST, Lopes da Silva FH (1992) Presynaptic dopamine D1 receptors attenuate excitatory and inhibitory limbic inputs to the shell region of the rat nucleus accumbens studied in vitro. J Neurophysiol 67:1325-1334. Medline

Pina M, Cunningham C (2014) Effects of dopamine receptor antagonists on the acquisition of ethanol-induced conditioned place preference in mice. Psychopharmacology (Berl) 231:459-468. CrossRef Medline

Piri M, Rostampour M, Nasehi M, Zarrindast MR (2013) Blockade of the dorsal hippocampal dopamine D1 receptors inhibits the scopolamineinduced state-dependent learning in rats. Neuroscience 252:460-467. CrossRef Medline

Rioult-Pedotti MS, Friedman D, Hess G, Donoghue JP (1998) Strengthening of horizontal cortical connections following skill learning. Nat Neurosci 1:230-234. CrossRef Medline

Seamans JK, Yang CR (2004) The principal features and mechanisms of dopamine modulation in the prefrontal cortex. Prog Neurobiol 74:1-58. CrossRef Medline

Stagg CJ, Nitsche MA (2011) Physiological basis of transcranial direct current stimulation. Neuroscientist 17:37-53. CrossRef Medline

Stagg CJ, Best JG, Stephenson MC, O’Shea J, Wylezinska M, Kincses ZT, Morris PG, Matthews PM, Johansen-Berg H (2009) Polarity-sensitive modulation of cortical neurotransmitters by transcranial stimulation. J Neurosci 29:5202-5206. CrossRef Medline

Stefan K, Kunesch E, Cohen LG, Benecke R, Classen J (2000) Induction of plasticity in the human motor cortex by paired associative stimulation. Brain 123:572-584. CrossRef Medline

Stefan K, Kunesch E, Benecke R, Cohen LG, Classen J (2002) Mechanisms of enhancement of human motor cortex excitability induced by interventional paired associative stimulation. J Physiol 543:699-708. CrossRef Medline 
Thirugnanasambandam N, Grundey J, Paulus W, Nitsche MA (2011) Dosedependent nonlinear effect of L-dopa on paired associative stimulationinduced neuroplasticity in humans. J Neurosci 31:5294-5299. CrossRef Medline

Ueki Y, Mima T, Kotb M, Sawada H, Saiki H, Ikeda A, Begum T, Reza F, Nagamine T, Fukuyama H (2006) Altered plasticity of the human motor cortex in Parkinson's disease. Ann Neurol 59:60-71. CrossRef Medline

Vijayraghavan S, Wang M, Birnbaum SG, Williams GV, Arnsten AF (2007) Inverted-U dopamine D1 receptor actions on prefrontal neurons engaged in working memory. Nat Neurosci 10:376-384. CrossRef Medline

Williams GV, Castner SA (2006) Under the curve: critical issues for elucidating D1 receptor function in working memory. Neuroscience 139:263276. CrossRef Medline
Witte AV, Flöel A (2012) Effects of COMT polymorphisms on brain function and behavior in health and disease. Brain Res Bull 88:418-428. CrossRef Medline

Witte AV, Kürten J, Jansen S, Schirmacher A, Brand E, Sommer J, Flöel A (2012) Interaction of BDNF and COMT polymorphisms on pairedassociative stimulation-induced cortical plasticity. J Neurosci 32:45534561. CrossRef Medline

Wolters A, Sandbrink F, Schlottmann A, Kunesch E, Stefan K, Cohen LG, Benecke R, Classen J (2003) A temporally asymmetric Hebbian rule governing plasticity in the human motor cortex. J Neurophysiol 89:2339_ 2345. CrossRef Medline

Zahrt J, Taylor JR, Mathew RG, Arnsten AF (1997) Supranormal stimulation of D1 dopamine receptors in the rodent prefrontal cortex impairs spatial working memory performance. J Neurosci 17:8528-8535. Medline 